Research, Society and Development, v. 9, n. 8, e130985552, 2020

(CC BY 4.0) | ISSN 2525-3409 | DOI: http://dx.doi.org/10.33448/rsd-v9i8.5552

Suplementação com plasma sanguíneo suíno desidratado em leitões ao nascimento:

efeitos no metabolismo de proteína e desempenho

Supplementation with spray-dried porcine plasma in piglets at birth: effects on protein metabolism and performance

Suplementación con plasma porcino secado por atomización en lechones al nacer: efectos sobre el metabolismo de las proteínas y rendimiento

Recebido: 12/06/2020 | Revisado: 12/06/2020 | Aceito: 14/06/2020 | Publicado: 27/06/2020

Dirceu Vicari Junior

ORCID: https://orcid.org/0000-0002-0256-7401

Universidade do Estado de Santa Catarina, Brasil E-mail: dirceu_vicarijr@hotmail.com

Fernando Zimmer

ORCID: https://orcid.org/0000-0002-3842-5528

Universidade do Estado de Santa Catarina, Brasil

E-mail: fernandozimmer2505@hotmail.com

Jeferson Gugel

ORCID: https://orcid.org/0000-0003-3127-4410

Universidade do Estado de Santa Catarina, Brasil

E-mail: je_gugel@hotmail.com

Gabriela Campigotto

ORCID: https://orcid.org/0000-0002-3615-7590

Universidade do Estado de Santa Catarina, Brasil

E-mail: gabriela.campigotto@hotmail.com

Fernando de Castro Tavernari

ORCID: https://orcid.org/0000-0002-3161-019X

EMBRAPA Suínos e Aves, Concórdia, SC, Brasil

E-mail: fernando.tavernari@embrapa.br

Marcel Manente Boiago

ORCID: https://orcid.org/0000-0002-0950-4577

Universidade do Estado de Santa Catarina, Brasil

E-mail: marcel.boiago@udesc.br 
Aleksandro Schafer da Silva

ORCID: https://orcid.org/0000-0002-6940-6776

Universidade do Estado de Santa Catarina, Brasil

E-mail: aleksandro_ss@yahoo.com.br

\section{Diovani Paiano}

ORCID: https://orcid.org/0000-0003-2715-9524

Universidade do Estado de Santa Catarina, Brasil

E-mail: diovani.paiano@udesc.br

\section{Resumo}

Este estudo foi planejado para avaliar se a suplementação de leitões com plasma sanguíneo suíno desidratado (PSSP) no dia do nascimento tem efeito positivo sobre o metabolismo proteico e ganho de peso (GP) em leitões, bem como no desempenho na fase de creche. Selecionamos 30 leitegadas de marrãs, das quais, no mínimo um casal de leitões para cada tratamento/leitegada foi selecionado. Os tratamentos foram: $\mathrm{TA}=$ controle sem PSSP, $\mathrm{TB}=$ administração oral de $10 \mathrm{~g}$ de PSSP e TC $=20 \mathrm{~g}$ de PSSP. No nascimento, os leitões foram pesados, identificados e distribuídos aleatoriamente. Os pesos corporais também foram avaliados nos dias 7, 14 e 19. Foram coletadas amostras de sangue para medir o nível de uréia, proteína total (PT), albumina (AB) e globulina (GB). No desmame, 70 leitões de cada tratamento foram distribuídos em cinco grupos (réplicas) de 14 leitões (sete machos e sete fêmeas). Os dados de pesos (animais e consumo de ração) foram coletados no pós-desmame e também a cada troca de dieta (dias 14, 28 e 42 da fase de creche). Durante as duas primeiras semanas na maternidade, não houve efeitos dos tratamentos para todas as variáveis avaliadas. Na terceira semana, os leitões de TC apresentaram níveis séricos mais altos para as variáveis PT e GB, mas o GT foi menor nos leitões comparado ao controle. Não houve efeito dos tratamentos no GT durante todo o período lactente. Não houve efeitos residuais no desempenho da fase de creche; no entanto, os leitões tratados tiveram menos necessidade de medicamentos. A suplementação com PSSP não influenciou o desempenho zootécnico nas duas primeiras semanas ou durante todo o período lactente. O grupo TC apresentou níveis mais altos de globulina do que o grupo TA. Na fase de creche, não houve efeitos no desempenho; no entanto, houve uma maior incidência de animais doentes do grupo TA.

Palavras-chave: Alimentação; Leitão; Suplementação. 


\section{Abstract}

This research was designed to evaluate whether supplementation of piglets with spray dried porcine plasma (SDPP) on the day of birth, have positive effect on protein metabolism and weight gain (WG) in suckling piglets, as well as on performance at the nursery phase. We selected 30 litters from gilts of at least one pair of piglets for each treatment, TA= control without SDPP, $\mathrm{TB}=$ oral administration of $10 \mathrm{~g}$ of SDPP, and $\mathrm{TC}=20 \mathrm{~g}$ of SDPP. At birth, the piglets were weighed, identified and randomly distributed. Body weights were also measured on days 7, 14 and 19. Blood samples were collected to measure the level of urea, total protein (TP), albumin (AB) and globulin (GB). At weaning, 70 piglets from each treatment were distributed in five groups (replicates) of 14 piglets (seven males and seven females). Weights (animals and feed intake) were taken at post-weaning and at each feed change (days 14, 28 and 42 of raising). During the first two weeks of lactation, there were no effects of the treatments for the all evaluated variables. In the third week, TC piglets had higher serum levels of TP and GB, but lower WG than did control piglets. There was no effect of treatments on WG during the entire suckling period. There were no residual effects on nursery phase performance; however, treated piglets had less need for medications. SDPP supplementation did not influence zootechnical performance in the first two weeks or during the entire suckling period. The TC group had higher globulin levels than did the TA group. In the weaning phase, there were no effects on performance; however, there was a higher incidence of diseased animals in the TA group.

Keywords: Creep feeding; Piglet; Supplementation.

\section{Resumen}

Este estudio fue diseñado para evaluar si la suplementación de lechones con plasma porcino secado por atomización (PPSA) el día del nacimiento, tiene un efecto positivo sobre el metabolismo de las proteínas y el aumento de peso (AP) en lechones lactantes, así como el rendimiento en la fase de cría. Seleccionamos 30 camadas de marranas al menos un par de lechones para cada tratamiento: $\mathrm{TA}=$ control sin PPSA, TB $=$ administración oral de $10 \mathrm{~g}$ de PPSA y $\mathrm{TC}=20 \mathrm{~g}$ de PPSA. Al nacer, los lechones fueron pesados, identificados $\mathrm{y}$ distribuidos al azar. Los pesos corporales también se midieron los días 7, 14 y 19. Se recogieron muestras de sangre para medir el nivel de urea, proteína total (PT), albúmina (AB) y globulina (GB). Al destete, se distribuyeron 70 lechones de cada tratamiento en cinco grupos (réplicas) de 14 lechones (siete machos y siete hembras). Los pesos (animales y consumo de alimento) se tomaron después del destete y en cada cambio de alimento (días 14, 
28 y 42 de crianza). Durante las primeras dos semanas de lactancia, no hubo efectos de los tratamientos para todas las variables evaluadas. En la tercera semana, los lechones TC tenían niveles séricos más altos de TP y GB, pero un AP más bajo que los lechones de control. No hubo efecto de los tratamientos sobre el AP durante todo el período de lactancia. No hubo efectos residuales en el rendimiento de la fase de vivero; sin embargo, los lechones tratados tenían menos necesidad de medicamentos. La suplementación con SDPP no influyó en el rendimiento zootécnico en las primeras dos semanas o durante todo el período de lactancia. El grupo TC tenía niveles de globulina más altos que el grupo TA. En la fase de destete, no hubo efectos en el rendimiento; sin embargo, hubo una mayor incidencia de animales enfermos en el grupo TA.

Palabras clave: Alimentación lenta; Lechón, Suplementación.

\section{Introduction}

Colostrum is a rich source of nutrients with high digestibility and with several bioactive compounds, such as immunoglobulins (especially $\operatorname{IgA}$ and $\operatorname{IgG}$ ), enzymes (lysozymes) and intestinal growth factors (oligosaccharides) (Wu et al., 2010). The main protein component of colostrum is immunoglobulins, which have their concentration reduced gradually after delivery (Vallet et al., 2013). In addition, the diffuse epithelial pig placenta (Miglino et al., 2001), prevents the passage of immunoglobulins during the gestation period, so that ingestion of colostrum is the only source of immunoglobulins for the neonatal piglet (Svendsen et al., 2005).

It is noteworthy that in contemporary pig farming, hyper-prolific females are preferred, as they are selected to produce large litters (Marantidis et al., 2013). The increased number of piglets born per litter decreases the piglets 'average weight at birth and their vitality, increases the competition for colostrum intake and can negatively affect piglets' survival (Oliviero et al., 2019). As for the production of colostrum Devillers et al., (2007) point to a trend of lower production in primiparous gilt $(3.44 \mathrm{~kg})$ when compared to sows with 2 and 3 births $(4.28 \mathrm{~kg})$. Despite the lower consumption of colostrum from litter of primiparous females, Ferrari et al., (2014) observed similar serum IgG concentrations at $24 \mathrm{~h}$ after birth.

Because of low feed intake in suckling piglets or the difficulties managing supplementation in neonatal pigs the nutrition-related techniques in piglets have predominantly focused on the nursery phase. Various studies of neonatal piglet supplementation reported reduced mortality (Declerck et al., 2016), increased IGF-1 
concentrations (Muns et al., 2017) and marginal increases in weight (Viott et al., 2018). Na fase de lactação, as técnicas visando a suplementação do leitão lactente rotineiramente tem como objetivos a suplementação nutricional e poucos trabalhos visam estudar estratégias para aumentar a imunidade passiva por meio do fornecimento de imunoglobulinas funcionais.

Among these techniques is the supply of Spray Dried Porcine Plasma (SDPP), a product with a history of beneficial effects in terms of zootechnical performance owing to its high digestibility and amino acid profile (Rostagno et al., 2017). Furthermore, immunoglobulins in SDPP remained 20\% functional after spray-dry processing (Pierce et al., 2005). According to Müller et al. (2018), weaned piglets supplemented with SDPP had better weight gain than did animals not receiving the SDPP.

Positive reports, on weight gain and feed intake, with SDPP use in the post-weaning diets are common in the literature (Lora Graña et al., 2010; Dalto et al., 2011; Remus et al., 2013; Weaver et al., 2014). The Spray Dried Animal Plasma improves feed efficiency more markedly when the piglets are challenged with an experimental infection or when feed does not contain medication, which could be indicative of a lower expenditure of energy and nutrients to build an immune response against the challenge (Torrallardona, 2010). In a study of neonatal supplementation of low-weight piglets with SDPP, Schuh et al. (2016) found higher gamma glutamyl transferase and nitric oxide activity, with no effect on weight gain at suckling phase.

Our hypothesis is that the use of the SDPP will help in the acquisition of passive immunity of neonatal piglets with improvement in the zootechnical and serum variables of piglets. Considering the benefits of post-weaning SDPP, as well as the low number of studies on neonatal SDPP piglet supplementation (Schuh et al., 2016), was designed the present study to evaluate whether supplementation of piglets with SDPP on the day of birth have positive effect on protein metabolism and weight gain in suckling piglets, as well as on performance during the nursery phase.

\section{Materials and Methods}

This research had an exploratory and quantitative nature (Pereira et al., 2018). To achieve the objectives of this study, we used a completely randomized design, as detailed below.

We used littermates from 30 gilts, selected from a commercial strain, adequate body condition scores (as established by the lineage manual) without previous reproductive 
Research, Society and Development, v. 9, n. 8, e130985552, 2020

(CC BY 4.0) | ISSN 2525-3409 | DOI: http://dx.doi.org/10.33448/rsd-v9i8.5552

problems such as abortion or infertility were additional criteria for the selection of gilts. Gilts were selected because her piglets consume less colostrum and show lower weight at 42 days than piglets from multiparous dams (Ferrari, 2014).

The study was carried out in a commercial farm producing piglets located in Santa Catarina, Brazil $\left(27^{\circ} 01^{\prime} \mathrm{S} ; 51^{\circ} 10^{\prime} \mathrm{W}\right)$ with a stock of approximately 600 females and an annual weaning rate of approximately 29 piglets/sow, and in band system with production cycles every 21 days. The maternity pens measured $0.6 \times 2.2 \mathrm{~m}$ for the female and additional lateral areas of $0.4 \times 2.2 \mathrm{~m}$ with a creep of $0.64 \mathrm{~m}^{2}$ for piglets. The maternity units had a nipple drinker type with a minimum flow rate of $3 \mathrm{~L} / \mathrm{min}$ for the sows and two nipple drinkers for the piglets with minimum flow of $0.5 \mathrm{~L} / \mathrm{min}$. The study was carried out in January and February of 2018. The maternity unit was equipped with thermometers positioned at the geometric center of the facilities, to record temperatures (recorded twice a day), obtaining a mean of $23.8 \pm 2.4{ }^{\circ} \mathrm{C}$ and $28.2 \pm 2.1{ }^{\circ} \mathrm{C}$ for morning and afternoon, respectively.

Management of the gilts followed the protocol adopted by the farm: transfer to the maternity stalls at approximately 107 days of gestation when the mothers had achieved 207.3 $\pm 13.1 \mathrm{~kg}$ body weight and backfat thickness $(\mathrm{P} 2)$ of $12.3 \pm 1.9 \mathrm{~mm}$. At weaning, sows presented $177.2 \pm 14.2 \mathrm{~kg}$ body weight and $11.0 \pm 1.1 \mathrm{~mm}$ of backfat thickness $(\mathrm{P} 2)$. The nutritional levels and the breeding program of the sows followed the current protocol on the farm. For lactation, prepartum and suckling piglets and in the nursery phase, rations were formulated based on corn, soybean meal, soybean oil and commercial basemix (Table 1). 
Table1 - Ingredients and nutritional composition of diets.

\begin{tabular}{|c|c|c|c|c|}
\hline Items & Lactation & Pre-starter I & Pre-starter II & Starter I \\
\hline \multicolumn{5}{|l|}{ Ingredients, ( $\mathrm{g} \mathrm{kg}^{-1}$ as fed basis) } \\
\hline Ground yellow corn & 677 & 340 & 465 & 632 \\
\hline Soybean meal, $45 \% \mathrm{~PB}$ & 235 & 140 & 260 & 300 \\
\hline Soybean oil & 40 & 20 & 25 & 18 \\
\hline Sow basemix ${ }^{1}$ & 48 & - & - & - \\
\hline Pre-starter pig basemix I ${ }^{2}$ & - & 500 & - & - \\
\hline Pre-starter pig basemix II $^{3}$ & - & - & 250 & - \\
\hline Starter pig basemix I ${ }^{4}$ & - & - & - & 50 \\
\hline \multicolumn{5}{|l|}{ Nutritional composition (as-fed basis) } \\
\hline Crude protein $\left(\mathrm{g} \mathrm{kg}^{-1}\right)$ & 174.0 & 192.7 & 198.1 & 191.8 \\
\hline Metabolizable energy, $\left(\mathrm{kcal} \mathrm{kg}^{-1}\right)$ & 3413 & 3535 & 3452 & 3328 \\
\hline Calcium $\left(\mathrm{g} \mathrm{kg}^{-1}\right)$ & 10.8 & 6.4 & 7.0 & 6.9 \\
\hline Phosphorus availability $\left(\mathrm{g} \mathrm{kg}^{-1}\right)$ & 4.9 & 3.4 & 3.6 & 3.4 \\
\hline Lysine digestible $\left(\mathrm{g} \mathrm{kg}^{-1}\right)$ & 9.9 & 14.1 & 13.4 & 12.4 \\
\hline
\end{tabular}

${ }^{1}$ Basemix minimum content per kg as-fed basis: Ca $165.67 \mathrm{~g}$; Cu $351.17 \mathrm{mg}$; Cr $9.37 \mathrm{mg}$; Fe $2342 \mathrm{mg}$; P 35 g; I 23.40 mg; carnitine 1041 mg; Phytase11666 FTU; Mn 1171 mg; Se 10.5 mg; Na 40.8 g; Zn $2812.6 \mathrm{mg}$; folic acid $93.70 \mathrm{mg}$; pantothenic acid $468 \mathrm{mg}$; biotin $10.55 \mathrm{mg}$; choline $12.5 \mathrm{~g}$; niacin 703 mg; vitamin A 233300 IU; B12 $703 \mu \mathrm{g}$; B2 117 mg; B6 70 mg; D3 46600 IU; vitamin E 1288 IU; K3 $58 \mathrm{mg}$; Lysine $46.67 \mathrm{~g}$; methionine $11.6 \mathrm{~g}$; threonine $35.0 \mathrm{~g}$; tryptophan $5833.3 \mathrm{mg}$; valine $23.3 \mathrm{~g}$; Bacillus lincheniforms $13.33 \times 10^{9}$ UFC; Bacillus subtilis $13.33 \times 10^{9}$ UFC.

${ }^{2}$ Basemix minimum content per kg: dry matter $910 \mathrm{~g}$; crude protein $200 \mathrm{~g}$; ether extract $50 \mathrm{~g} ; \mathrm{P} 7 \mathrm{~g}$; Ca 9 g; Na 6.5 g; Co 1.6 mg; Cu 400 mg; Fe 400 mg; I 3.6 mg; Mn 110 mg; Se 0.6 mg; Zn 6 g; Cr 0.6 mg; vitamin A $23000 \mathrm{IU}$; vitamin D3 $5000 \mathrm{IU}$; vitamin E $80 \mathrm{IU}$; nicotinic acid $70 \mathrm{mg}$; pantothenic acid $44 \mathrm{mg}$; choline $264 \mathrm{mg}$; biotin $0.2 \mathrm{mg}$; lysine $21 \mathrm{~g}$; methionine $8000 \mathrm{mg}$; phytase $1000 \mathrm{FTU}$ and xylanase $4500 \mathrm{EPU}$, basemix maximal content per kg: crude fiber $20 \mathrm{~g}$; $\mathrm{Ca} 14 \mathrm{~g}$ and ashes $400 \mathrm{~g}$.

${ }^{3}$ Basemix minimum content per kg as-fed basis: dry matter $950 \mathrm{~g}$; crude protein $160 \mathrm{~g}$; ether extract 35g; P 10 g; Ca 18 g; Na 12 mg; Co 3.2 mg; Cu 800 mg; Fe 800 mg; I 7.2 mg; Mn 220 mg; Se 1.2 mg; Zn 10 g; Cr 1.2 mg; vitamin A 45000 IU; vitamin D3 10000 IU; vitamin E160 IU; nicotinic acid 140 $\mathrm{mg}$; pantothenic acid $88 \mathrm{mg}$; choline $1245 \mathrm{mg}$; biotin $0.4 \mathrm{mg}$; lysine $25 \mathrm{~g}$; methionine $9000 \mathrm{mg}$; phytase $32000 \mathrm{FTU}$ and xylanase $9000 \mathrm{EPU}$. ${ }^{4}$ Basemix maximal content per kg: crude fiber $20 \mathrm{~g}$; $\mathrm{Ca}$ $24 \mathrm{~g}$; ashes $450 \mathrm{~g}$.

${ }^{4}$ Basemix minimum content per kg as-fed basis: dry mater $940 \mathrm{~g}$; crude protein $150 \mathrm{~g}$; ether extract 35g; Ca 90 g; P 37g; Na 35 mg; Co 11 mg; Cu 4750 mg; Fe 1850 mg; I 18 mg; Mn 1000 mg; Se 7 mg; Zn 1700 mg; vitamin A 172800 IU; vitamin D3 34500 IU; vitamin E 384 IU; vitamin K3 57 mg; vitamin B1 $26 \mathrm{mg}$; vitamin B2 $76 \mathrm{mg}$; vitamin B6 $28 \mathrm{mg}$; vitamin B12 $345 \mu \mathrm{g}$; folic acid $7.5 \mathrm{mg}$; nicotinic acid $575 \mathrm{mg}$; pantothenic acid $305 \mathrm{mg}$; choline $2950 \mathrm{mg}$; Biotin $1.9 \mathrm{mg}$; Lysine $75 \mathrm{~g}$; methionine 45 g; Phyase12000 FTU e Xylanase30000 EPU and Flavomicin 80 mg. Basemix maximal content per kg as-fed basis: Crude fiber $20 \mathrm{~g}$ and $\mathrm{Ca} 140 \mathrm{~g}$. Source: Authors.

Three treatments were as follows: $\mathrm{TA}=$ no administration of SDPP, used as a negative control; TB = administration of $10 \mathrm{~g}$ of SDPP; and TC $=$ administration $20 \mathrm{~g}$ of SDPP. On the day of birth, administration of SDPP was performed by orogastric tube in order to guarantee consumption, in a single application for TB and two applications of $10 \mathrm{~g}$ for the TC, performed within 4 hours after birth in order not to overload the digestive system. The SDPP was previously diluted in distilled water, according to a methodology adapted from Schuh et al. (2016) (without the use of EDTA) in a ratio of water: SDPP of 2:1. 
From each litter, we randomly selected at least one pair of piglets (one male and one female) for each treatment/litter, this way each litter had all the treatments, when possible more pairs were used in the same litter. At least 40 pairs of piglets were used per treatment considering all the littermates. In the case of homogenization of litters, only piglets not used in the treatments were transferred. Other handling, such as castration, iron supplementation, anticoccidial, teeth grinding, caudectomy and others were performed according to the farm protocols.

At birth, all selected piglets (6-12 piglets/littermate) from each littermate were weighed and identified individually with plastic earrings according to the order of birth. The additional weighings were carried out on days 7,14 and 19 to evaluate weekly growth until weaning at 19 day. For the nursery phase, just 70 weaning piglets from the suckling phase, were randomly selected from each treatment (210 weaned piglets enough to set a nursery facilities) and were randomly assigned to five pens of 14 piglets (seven females and seven castrated males). Body weight at weaning and weighing at each feed change (14, 28 and 42 days of raising) were calculated as weight gain. On the same days, feed intake (FI) and feed:gain ratio (FGR) were calculated. Performance was calculated per pen, initially formed by 14 piglets, such that death or withdrawal for low performance were aggregated to the gain and FGR estimates.

In the sucking phase, $5 \mathrm{~mL}$ of blood were collected through the cranial vena cava, on the 2 nd day and on days when weighing was performed. In order to minimize handling (pick up and holding the pigs) and avoid stress and reduce the welfare of piglets, blood was collected only from 10 males/treatment, randomly selected from each treatment. The blood centrifuged for fifteen minutes with a relative centrifugal force (RCF) of 1,500 $g$ to obtain serum, which in turn was placed in plastic microtubes and frozen at $-20^{\circ} \mathrm{C}$ for analysis of urea, total protein and albumins using specific commercial kits (Analiza). Parameters were measured on a semi-automatic biochemical analyzer (Bioplus 2000). Globulin levels were determined by the following expression: globulins $=$ total proteins - albumin .

In the nursery phase, in addition to the planned collections, numbers of animals affected by illness and respective medication therapies were counted. The procedures, when necessary, were performed by the farm staff who recorded the diseased and treated animals and the medications used. The total number of medications administered (number of medications in the period) was calculated for pens during the first and second week. There were no drug interventions in the subsequent weeks. 
Data from the suckling phase were analyzed according to the following statistical model: $Y_{i j}=\mu+T_{i}+S_{j}+T_{i j}+e_{i j}$, where $Y=$ value of the variable tested under the $i$-th treatment of factor $\mathrm{T}$ and $\mathrm{j}$-th gender, $\mu=$ general average associated with all observations, $\mathrm{T}_{\mathrm{i}}$ $=$ effect of the $\mathrm{i}$-th treatment (negative control, 10 or $20 \mathrm{~g}$ of SDPP supplementation), $\mathrm{S}_{\mathrm{j}}=$ effect of the $\mathrm{i}$-th gender (male or female), $\mathrm{TS}_{\mathrm{ij}}=$ effect of interaction between gender and treatment, $e_{i}=$ random error associated with all observations. The same model was adopted for biochemical analyses and for the weaning phase, excluding gender and interaction (since blood samples were collected only in males). Performance in the nursery phase was analyzed for females and males together.

Before the analysis, the data were subjected to normality testing by the Shapiro-Wilk test $(\alpha>0.05)$. The WG data for the suckling phase, except for gains in the first two weeks, were not normal $(\alpha<0.05)$ and were transformed according to box-cox (first week gain and total gain) and Johnson transformations (gain in the second week and gain in the third week) for standardization.

Biochemical parameters, except for albumin, showed no normal distribution and were transformed (log 10). Serum parameters were subjected to a two-way analysis of variance for comparison between groups and repeated measures over time (days 2, 7, 14 and weaning). The results for weight gain and biochemistries were presented as means and standard deviations. In the case of effects, the means were compared by the Tukey test $(p<0.05)$.

\section{Results and Discussion}

In the suckling phase, there was no interaction between gender and treatment $(p>0.05)$ or effect of the genders on weight gain $(p>0.05)$. There was no effect $(p>0.05)$ of the treatments on weight gains in the first, first and second weeks or during the total period (Table 2).

In the third week, piglets from the control group had higher weight gain $(\mathrm{P}<0.05)$ than did piglets in the TC group (20 g of SDPP). Weight gain in the third week of the TB group (10 $\mathrm{g}$ of SDPP) did not differ from that of the other treatments $(\mathrm{P}>0.05)$. 
Table 2 - Post-natal performance (means \pm SE) of piglets treated with different SDPP supplementation protocols at birth.

\begin{tabular}{|c|c|c|c|c|c|c|c|c|}
\hline & \multicolumn{3}{|c|}{ Treatments } & \multicolumn{2}{|c|}{ Gender } & \multicolumn{3}{|c|}{ P-value } \\
\hline & $\begin{array}{c}\text { A } \\
\text { (Control) }\end{array}$ & B (10 g) & $\mathrm{C}(20 \mathrm{~g})$ & q & 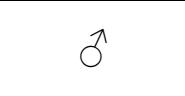 & & & \\
\hline & \multicolumn{5}{|c|}{ Body weight (kg) } & $\mathrm{T}$ & $S$ & $\mathrm{~T} * \mathrm{~S}$ \\
\hline $\begin{array}{l}\text { Birth } \\
\text { day }\end{array}$ & $1.42 \pm 0.21$ & $1.43 \pm 0.24$ & $1.41 \pm 0.21$ & $1.41 \pm 0.24$ & $1.43 \pm 0.20$ & - & - & - \\
\hline $7^{\text {th }}$ day & $2.12 \pm 0.51$ & $2.09 \pm 0.48$ & $2.06 \pm 0.44$ & $2.09 \pm 0.48$ & $2.10 \pm 0.48$ & - & - & - \\
\hline $14^{\text {th }}$ day & $3.68 \pm 0.70$ & $3.67 \pm 0.65$ & $3.64 \pm 0.62$ & $3.71 \pm 0.65$ & $3.63 \pm 0.66$ & - & - & - \\
\hline Weaning & $5.37 \pm 0.99$ & $5.22 \pm 0.82$ & $5.12 \pm 0.84$ & $5.22 \pm 0.94$ & $5.26 \pm 0.85$ & - & - & - \\
\hline \multicolumn{9}{|c|}{ Weight gain (kg) } \\
\hline $1^{\text {st }}$ week & $0.71 \pm 0.42$ & $0.67 \pm 0.44$ & $0.67 \pm 0.38$ & $0.70 \pm 0.40$ & $0.67 \pm 0.43$ & 0.884 & 0.523 & 0.678 \\
\hline $2^{\text {nd }}$ week & $1.56 \pm 0.34$ & $1.57 \pm 0.37$ & $1.55 \pm 0.37$ & $1.60 \pm 0.35$ & $1.52 \pm 0.37$ & 0.880 & 0.164 & 0.334 \\
\hline $3^{\text {rd }}$ week & $1.71 \pm 0.5^{\mathrm{a}}$ & $1.56 \pm 0.4^{\mathrm{ab}}$ & $1.52 \pm 0.46^{\mathrm{b}}$ & $1.56 \pm 0.51$ & $1.63 \pm 0.44$ & 0.032 & 0.360 & 0.978 \\
\hline $14^{\text {th }}$ day & $2.26 \pm 0.61$ & $2.23 \pm 0.59$ & $2.23 \pm 0.56$ & $2.30 \pm 0.56$ & $2.20 \pm 0.60$ & 0.946 & 0.219 & 0.704 \\
\hline Total & $3.95 \pm 0.88$ & $3.79 \pm 0.78$ & $3.72 \pm 0.76$ & $3.82 \pm 0.85$ & $3.83 \pm 0.78$ & 0.223 & 0.836 & 0.815 \\
\hline
\end{tabular}

Means in the same rows followed by different letters are different by the Tukey test $(\mathrm{P}<0.05)$. ns- not significant. n column differ $(P<0.05)$. Source: Authors

The treatments did not influence $(p>0.05)$ the results for urea or albumin. Total protein and globulin were not influenced $(\mathrm{p}>0.05)$ in the second week. However, at weaning, TC animals had higher values $(\mathrm{p}<0.05)$ than did controls for total protein and globulin levels, and levels in TB piglets did not differ from those of other treatments ( $p>0.05$ ) (Table 3).

Furthermore, we found that levels of albumin increased $(\mathrm{p}<0.05)$ with increased piglet age, while urea levels decreased after the second week. The concentration of globulins in the blood of control piglets was lower than weaning values when compared to the second day of life. The same phenomenon, lower globulin levels compared to the second day of life, occurred on the $14^{\text {th }}$ day for treatments $\mathrm{TB}$ and $\mathrm{TC}(\mathrm{p}<0.05)$. At weaning, the values of globulins in treatments TB and TC did not differ from those of other days ( $p>0.05$ ).

The absence of effects on weight gain in the first weeks of the suckling phase may have been associated with colostrum intake during the first hours of life, because the nutritional composition of colostrum is important for piglet development (Wu et al., 2010). Alternatively, the absence of effects on weight gain may have been associated with the low nutrient contents provided in the TB and TC groups (10 or $20 \mathrm{~g}$ of SDPP/piglet, respectively) that probably were insufficient to result in differences in weight gain during the suckling phase. However, we reinforce that our main objective was access priority to the nutraceutical effects of SDPP. 
Table 3 - Blood variables (means \pm SE) of pigs treated with different SDPP supplementation protocols at birth.

\begin{tabular}{|c|c|c|c|c|}
\hline Days & A (Control) & $\mathrm{B}(10 \mathrm{~g})$ & $\mathrm{C}(20 \mathrm{~g})$ & P-value \\
\hline \multicolumn{5}{|c|}{ Urea $\left(\mathrm{mg} \mathrm{dL}^{-1}\right)$} \\
\hline 2 & $50.3 \pm 20.6^{\mathrm{A}}$ & $57.6 \pm 14.5^{\mathrm{A}}$ & $69.0 \pm 22.5^{\mathrm{A}}$ & 0.095 \\
\hline 7 & $18.1 \pm 9.1^{\mathrm{B}}$ & $18.2 \pm 8.0^{\mathrm{B}}$ & $20.9 \pm 8.3^{\mathrm{B}}$ & 0.745 \\
\hline 14 & $21.8 \pm 10.6^{\mathrm{B}}$ & $24.3 \pm 12.1^{\mathrm{B}}$ & $25.3 \pm 5.9^{\mathrm{B}}$ & 0.654 \\
\hline Weaning & $23.2 \pm 13.0^{\mathrm{B}}$ & $22.5 \pm 7.9^{\mathrm{B}}$ & $20.5 \pm 8.1^{\mathrm{B}}$ & 0.728 \\
\hline P-value & 0.001 & 0.001 & 0.001 & \\
\hline \multicolumn{5}{|c|}{ Total blood proteins $\left(\mathrm{mg} \mathrm{dL}^{-1}\right)$} \\
\hline 2 & $9.82 \pm 3.05$ & $9.43 \pm 3.16$ & $8.38 \pm 2.10$ & 0.456 \\
\hline 7 & $8.14 \pm 1.81$ & $8.22 \pm 1.12$ & $7.87 \pm 1.89$ & 0.845 \\
\hline 14 & $6.78 \pm 1.93$ & $7.21 \pm 2.11$ & $7.14 \pm 1.13$ & 0.814 \\
\hline Weaning & $7.03 \pm 1.25^{b}$ & $8.14 \pm 1.62^{\mathrm{ab}}$ & $8.73 \pm 1.58^{\mathrm{a}}$ & 0.042 \\
\hline P-value & 0.154 & 0.356 & 0.654 & \\
\hline \multicolumn{5}{|c|}{ Albumin $\left(\mathrm{mg} \mathrm{dL}^{-1}\right)$} \\
\hline 2 & $1.73 \pm 0.66^{\mathrm{B}}$ & $1.78 \pm 0.61^{\mathrm{B}}$ & $2.01 \pm 0.74^{\mathrm{C}}$ & 0.604 \\
\hline 7 & $2.73 \pm 0.84^{\mathrm{AB}}$ & $2.81 \pm 0.53^{\mathrm{A}}$ & $2.75 \pm 0.49^{\mathrm{BC}}$ & 0.925 \\
\hline 14 & $3.15 \pm 0.71^{\mathrm{A}}$ & $3.35 \pm 0.59^{\mathrm{A}}$ & $3.38 \pm 0.57^{\mathrm{AB}}$ & 0.747 \\
\hline Weaning & $3.48 \pm 0.63^{\mathrm{A}}$ & $3.57 \pm 0.60^{\mathrm{A}}$ & $3.48 \pm 0.56^{\mathrm{A}}$ & 0.945 \\
\hline P-value & 0.001 & 0.001 & 0.001 & \\
\hline \multicolumn{5}{|c|}{ Globulin $\left(\mathrm{mg} \mathrm{dL}^{-1}\right)$} \\
\hline 2 & $8.09 \pm 2.65^{\mathrm{A}}$ & $6.65 \pm 2.67^{\mathrm{A}}$ & $6.37 \pm 1.70^{\mathrm{A}}$ & 0.167 \\
\hline 7 & $5.42 \pm 1.44^{\mathrm{AB}}$ & $5.45 \pm 0.78^{\mathrm{AB}}$ & $5.12 \pm 1.89^{\mathrm{AB}}$ & 0.882 \\
\hline 14 & $3.63 \pm 1.54 \mathrm{AB}$ & $3.85 \pm 1.78^{\mathrm{B}}$ & $3.76 \pm 0.99^{\mathrm{B}}$ & 0.914 \\
\hline Weaning & $3.55 \pm 1.01^{b ; B}$ & $4.58 \pm 1.51^{\mathrm{ab} ; \mathrm{AB}}$ & $5.13 \pm 1.48^{\mathrm{a} ; \mathrm{AB}}$ & 0.035 \\
\hline P-value & 0.001 & 0.036 & 0.041 & \\
\hline
\end{tabular}

Two-way ANOVA followed by Tukey's test; Means values followed by the different lowercase letters in the rows and by capital letters on column differ $(P<0.05)$. Source: Authors.

SDPP has about $780 \mathrm{~g} \mathrm{~kg}^{-1}$ of crude protein; therefore, it is characterized as a protein supplement. Nevertheless, newborn piglets have high energy demands, because of their substantial physical activity, their need for thermoregulation (with low body fat content and low insulation) and high heat production by their muscles (Theil et al., 2014). Protein supplementation in suckling piglets was studied by Kummer et al. (2015); they saw no results in weight gain. In the same way Viott et al. (2018) reported that colostrum intake and preweaning mortality of low birth-weight piglets are not affected by nutritional manipulation through the administration of extra colostrum and/or a protein-energy supplement during the first hours of life, corroborating our findings and reinforcing the hypothesis that energy demand is the limiting factor in the first few days after birth.

Urea levels indicate protein catabolism and found higher urea levels on the second day of life, for all treatments, comparatively with another's days, suggesting high catabolism of 
amino acids and reinforcing the notion that energy is the main limiting factor in the first day's post-birth. Viott et al. (2018) found a marginal increase in weight gain of low-viability piglets, and Declerck et al. (2016) reported a reduction in the percentage of mortality of lowviability piglets associated with neonatal supplementation. The energetic supplementation in these studies was positive in the sense of minimizing the catabolism of amino acids, consequent increase in weight gain and reduction in mortality.

It is noteworthy that supplementation with $20 \mathrm{~g}$ of SDPP, according to the chemical composition proposed by Rostagno et al. (2017), provides approximately $14.36 \mathrm{~g}$ of crude protein, $0.79 \mathrm{~g}$ of arginine and $1.17 \mathrm{~g}$ of glutamic acid. However, colostrum of a lactating sow, approximately 3 hours postpartum, provides about $16.6 \mathrm{~g}$ of crude protein, $0.76 \mathrm{~g}$ of arginine and $2.95 \mathrm{~g}$ of glutamic acid/100 mL colostrum, respectively (Hurley, 2015) and primiparous sow colostrum, provides about $166 \mathrm{~g} \mathrm{~kg}^{-1}$ of crude protein and $0.498 \mathrm{Mcal} \mathrm{kg}^{-1}$ (Craig et al., 2019).

The weight gain obtained in the suckling phase was similar to the results presented by Schuh et al. (2016) in a study of SDPP supplementation in neonatal piglets characterized as having low weight, they did not observe effects on piglet weight gain when supplemented with $10 \mathrm{~g}$ of SDPP at birth. However, our main goal with SDPP supplementation was to explore the nutraceutical characteristics of SDPP and to increase the passive immunity of sulking piglets. The lower weight gain in the third week of TC piglets ( $20 \mathrm{~g}$ of SDPP) when compared to that of the control group was not expected, because of the nutraceutic effect of SDPP. On the other hand, benefits associated with the use of SDPP that had been previously reported with SDPP use in diets to weaned pigs, including higher weight gain and lower incidence of diarrhea (Müller et al., 2018).

The early stimulation of the immune system in treatment TC, shown by increased levels of globulins (Table 3), may have been a factor that contributed to the reduction of weight gain in the third week when compared to piglets in the control group. Immunoglobulin have different amino acid profiles from those of muscle tissue, and therefore there are different nutritional requirements for these tissues.

The early stimulation of the immune system hypothesis is supported by our serum data, in which globulin levels were higher in TC piglets than in the control group. Similar results were obtained by Muns et al. (2017), who verified an increase in IGF-1on the $21^{\text {st }}$ day life when they tested neonatal supplementation with various energy sources. Although the result in the third week may have been lower for the TC treatment pigs (20 g of SDP). Ours hypothesis of the piglets from treatment $\mathrm{C}$ may have future benefits, especially in post- 
(CC BY 4.0) | ISSN 2525-3409 | DOI: http://dx.doi.org/10.33448/rsd-v9i8.5552

weaning, because they have more mature immune systems, leading to residual effect of the treatment on the performance in the nursery phase was not confirmed.

The levels of urea obtained at weaning were close to the values considered normal (4$18 \mathrm{mg} \mathrm{dL}^{-1}$ for 6-week-old piglets as proposed by Cooper et al. (2014) and values of $2-17$ $\mathrm{mg} \mathrm{dL} \mathrm{d}^{-1}$ for piglets close to weaning Perry et al. (2017)). The piglet's levels of blood urea obtained on the $2^{\text {nd }}$ day of life were significantly higher than those of other days and were substantially higher than the reference values mentioned. Such results are probably associated with previously discussed factors as high energetic demand and consequently high protein metabolism in order to obtain energy. In a study to evaluate intestinal-level amino acid metabolism in weaned piglets at 28 days, Stoll et al. (1998) observed that only $56 \%$ of the essential amino acids ingested were recovered in the portal vein and that catabolism for energy production was the main form of consumption of amino acids.

Total serum protein levels in treatments $\mathrm{TB}$ and $\mathrm{TC}$ at weaning (Table 3) were higher than those of the reference levels for weaning piglets from 4.4 to $7.4 \mathrm{mg} \mathrm{dL}^{-1}$ (Leman et al., 1992). Only piglets in the control treatment group were within the reference range. This reinforces the hypothesis that treatments $\mathrm{TB}$ and $\mathrm{TC}$ modulated and stimulated the immune system of the piglets, limiting the amino acids for muscle growth and resulting in a fall in weight gain in the third week. Table 4 shows performance of piglets in the nursery phase treated with different protocols of SDPP supplementation at birth.

Serum globulin levels in the control treatment $\left(3.55 \mathrm{mg} \mathrm{dL}^{-1}\right)$, TB $\left(4.58 \mathrm{mg} \mathrm{dL}^{-1}\right)$ and TC (5.13 $\left.\mathrm{mg} \mathrm{dL}^{-1}\right)$ groups at weaning were higher than the reference levels proposed by Cooper et al. (2014) (0.3 to $1.7 \mathrm{mg} \mathrm{dL}^{-1}$ ) for 6-week-old piglets. This may indicate that the animals used in our study had greater activation of the immune system. Dalto et al. (2013), in a study in which the piglets were supplemented with SDPP at post-weaning, found improvements in immune responses in terms of fecal IgA levels in piglets considered to be low weight at weaning.

Albumin levels in the control $\left(3.48 \mathrm{mg} \mathrm{dL}^{-1}\right)$, TB $\left(3.57 \mathrm{mg} \mathrm{dL}^{-1}\right)$ and $\mathrm{TC}\left(3.48 \mathrm{mg} \mathrm{dL}^{-1}\right)$ groups were within the reference range for animals at weaning, 1.9 to $3.9 \mathrm{mg} \mathrm{dL}^{-1}$ (Leman et al., 1992) and 3.1 to 4.8 (Cooper et al., 2014). The increase in albumin levels throughout the lactation period was associated with the physiological maturation of the piglet, because it is a protein synthesized by the liver, a metabolically active tissue (Kaneko et al., 1997). 
Table 4 - Performance of piglets in nursery phase treated with different protocols of SDPP supplementation at birth.

\begin{tabular}{lccccc}
\hline Days & A (Control) & B $(10 \mathrm{~g})$ & $\mathrm{C}(20 \mathrm{~g})$ & Means & P-value \\
\hline \multicolumn{5}{c}{ Body weight $(\mathrm{kg})$} \\
\hline Weaning & 5.40 & 5.28 & 5.18 & 5.29 & - \\
$14^{\text {th }}$ day & 6.90 & 6.90 & 6.78 & 6.86 & - \\
$27^{\text {nd }}$ day & 11.33 & 11.33 & 11.01 & 11.22 & - \\
$42^{\text {nd }}$ day & 18.94 & 18.37 & 17.83 & 18.38 & - \\
\hline \multicolumn{5}{c}{ Feed intake/pens/period $(\mathrm{kg})$} \\
\hline $0-13$ & 27.8 & 27.5 & 28.2 & 27.8 & 0.953 \\
$0-27$ & 110.9 & 109.9 & 110.6 & 110.5 & 0.986 \\
$0-42$ & 245.3 & 243.0 & 240.1 & 242.8 & 0.896 \\
\hline \multicolumn{5}{c}{ Weight gain/pens/period (kg) } \\
\hline $0-13$ & 21.0 & 21.4 & 22.5 & 0.830 \\
$0-27$ & 78.5 & 82.4 & 81.6 & 21.6 \\
$0-42$ & 174.6 & 176.1 & 169.8 & 0.829 \\
\hline \multicolumn{5}{c}{ Feed:gain ratio/pens/period } \\
\hline $0-13$ & 1.34 & 1.30 & 1.29 & 173.5 & 0.851 \\
$0-27$ & 1.43 & 1.34 & 1.37 & 0.880 \\
$0-42$ & 1.41 & 1.38 & 1.42 & 1.31 \\
\hline
\end{tabular}

Mean values obtained from pens initially formed by 14 pigs (seven males and seven females), in which the mortalities and discards of low viability pigs were computed. Source: Authors.

The lack of effects on zootechnical performance in the nursery phase may be associated with several factors as insufficient postpartum SDPP supplementation levels to provide postweaning effects, absence of treatment effect, compensation of supplementation in the control group by consumption of colostrum and similar intake of piglet ration among treatments, among others. Another factor to be considered and previously discussed is that SDPP may have modulating effects on the immune system that may cause a change in the nutritional profile of amino acids required by the animal, leading to the need to change the nutritional profile of the diets. As the same diets were used between the treatments, the diets may have limited the growth of the animal, because piglets in the various treatment groups had different nutritional requirements; consequently, there were no differences in the zootechnical performances during the weaning period.

On the other hand, TB piglets (10g of SDPP at birth) provided lower FCBW; these results were probably associated with higher cases of disease and mortality that occurred in the control treatment group (Table 5). 
Table 5 - Number of pigs, discarded by low weight, deaths during total period or treated for disease during the first and second weeks in nursery phase.

\begin{tabular}{|c|c|c|c|c|c|}
\hline & $\begin{array}{c}\mathrm{A} \\
\text { (Control) }\end{array}$ & $\mathrm{B}(10 \mathrm{~g})$ & $\mathrm{C}(20 \mathrm{~g})$ & Means & $\mathrm{CV}=$ \\
\hline Deceased and low-viability pig & 4 & 2 & 2 & - & - \\
\hline \multicolumn{6}{|c|}{ Number of medications/pens } \\
\hline $1^{\text {st }}$ and $2^{\text {nd }}$ week & 27.6 & 23.2 & 17.0 & 22.6 & 66.3 \\
\hline
\end{tabular}

Source: Authors

It is important to emphasize that the survival rate and performance of the piglets postweaning is a characteristic of low heritability, therefore it is related primarily to environmental factors such as nutrition, sanitation, management and facilities (Quesnel et al., 2012).

The application of SDPP on the first day of life may have stimulated the immune system of treated piglets such that the impact of weaning was lower for the treated group. Consequently, there was less need for drug interventions. As previously discussed, TC animals had higher globulin levels at weaning than did controls, possibly explaining the lower number of drug interventions in the TB and TC treatment groups. In a previously cited study by Schuh et al. (2016), in which SDPP supplementation was evaluated at birth, there was a reduction in serum nitric oxide levels, an important mediator of the inflammatory response that may also have contributed to the responses obtained in the present study.

Another point to be considered is that the higher incidence of drug interventions in the control group may have contributed to the lack of effects on zootechnical performance in the evaluated treatments, because the additional effects of antimicrobial use may have compensated in the control treatment group, possibly benefiting the animals in the TB and TC groups, minimizing the possible beneficial effects of neonatal SDPP supplementation. A relevant fact that hinders the discussion of our results is the limited number of studies with methodologies similar ours (neonatal supplementation of piglets) and recording of possible effects until the end of the weaning period, making it difficult to compare ours to the results in literature; however, this points to the need for further studies, in particular studies related to the changing nutritional requirements of piglets supplemented at birth. 


\section{Final Considerations}

SDPP supplementation did not influence zootechnical performance in the first two weeks or during the entire suckling period. The TC group had higher globulin levels than did the TA group. In the weaning phase, there were no effects on performance; however, there was a higher incidence of diseased animals in the TA group.

\section{Ethics Committee}

This study was conducted according to ethical standards and was approved by the Ethics Committee on the use of Animals in Research (CEUA) of the State University of Santa Catarina under the protocol number 3828300517.

\section{Conflict of Interest}

The authors declare that they have no conflict of interest.

\section{Financial Support and Acknowledgments}

We thank CAPES, CNPq and FAPESC for their technical and financial support.

\section{References}

Cooper, C. A., Moraes, L. E., Murray, J. D., \& Owens, S. D. (2014). Hematologic and biochemical reference intervals for specific pathogen free 6-week-old Hampshire-Yorkshire crossbred pigs. Journal of Animal Science and Biotechnology. 5, 1-5.

Dalto, D. B., Silva, C. A., Bridi, A. M., Gavioli, D. F., Oliveira, E. R., Silva, R. A. M., Tarsinato, M. A., Altmann, A. H. S., Braz, D. B., Kobayashi, R. K. T., \& Venâncio, E. J. (2011). Plasma sanguíneo desidratado na recuperação de leitões leves ao desmame: Desempenho zootécnico, perfil hematológico, frequência de diarreia e viabilidade econômica. Semina: Ciências Agrárias 32, 1989-2000. 
Dalto, D. B., Gavioli, D. F., Oliveira, E. R., Silva R. A. M., Tarsitano. M. A., Altmann, A. H. S., Braz, D. B., Kobayashi, R. K. T., Venâncio, E. J., Bridi, A. M., Bracarense, A. P. F. R. L. \& Silva, C. A. (2013). Efeito de dietas contendo plasma sanguíneo desidratado sobre características microbiológicas, imunológicas e histológicas de leitões leves ao desmame. Arquivo Brasileiro Medicina Veterinária e Zootecnia 65,189-197.

Declerck, I., Dewulf, J., Decaluwé, R., \& Maes, D. (2016). Effects of energy supplementation to neonatal (very) low birth weight piglets on mortality, weaning weight, daily weight gain and colostrum intake. Livestock Science 183,48-53.

Oliviero, C., Junnikkala, S., \& Peltoniemi, O. (2019) The challenge of large litters on the immune system of the sow and the piglets. Reproduction in Domestic Animals. 54(Suppl 3), $12-21$.

Ferrari, C. V., Sbardella, P. E., Bernardi, M. L., Coutinho, M. L., Vaz, I. S. J. R., Wentz, I., \& Bortolozzo, F. P. (2014). Effect of birth weight and colostrum intake on mortality and performance of piglets after cross-fostering in sows of different parities. Preventive Veterinary Medicine 114, 259-266.

Craig, J. R., Dunshea, F. R., Cottrell, J. J., Wijesiriwardana, U. A., \& Pluske, J. R. (2019) Primiparous and multiparous sows have largely similar colostrum and milk composition profiles throughout lactation. Animals 35, 1-12

Hurley, R. (2015). Composition of sow colostrum. p. 193-230. In: The gestating and lactating sow. 1st ed. Chantal Farmer (Orgs.). Wageningen Academic Publishers, Wageningen.

Kaneko, J.; Harvey, J. \& Bruss, M. (1997). Clinical Biochemistry of Domestic Animals. $5^{\text {th }}$ ed. California: Academic Press, California.

Kummer, A. D., Baroncello, E., Moreira, L. P., Bernardi, M. L., Bortolozzo, F. P., \& Wentz, I. (2015). Efeitos do fornecimento oral de suplementos nutricionais na sobrevivência e crescimento de leitões de baixo peso ao nascer. Acta Scientiae Veterinariae 43, 1336-1344.

Leman, A. D.; Straw, B. E. E. \& Mengeline, W. L. 1992. Diseases of swine. $7^{\text {th }}$ ed. Ames: Iowa State University Press, Iowa. 
Lora Graña, G., Ferreira, A. S., Silva, F. C. O., Lora Graña, A., Araújo, W. A. G., \& Carlos, C. M. (2010). Plasma sanguíneo em dietas sem antibióticos para leitões desmamados aos 21 dias de idade. Revista Brasileira de Saúde e Produção Animal 11, 815-826.

Marantidis, A., Papadopoulos, A. L, Michailidis, G., \& Avdi, M. (2013). Association of BF gene polymorphism with litter size in a commercial pig cross population. Animal Reproduction Science 141, 75-79.

Miglino, M. A., Pereira, F. T. V., Santos, T. C., \& Carvalho, A. F. A. (2001) Morfologia placentária dos suínos domésticos - revisão. Arquivos de Ciências Veterinária e Zoologia UNIPAR 4, 71-76.

Müller, L. K. F., Paiano, D., Gugel, J., Lorenzetti, W. R., Santurio, J. M., Tavernari, F.C., Gloria, E. M., Baldissera, M. D., \& Silva, A. S. (2018). Post-weaning piglets fed with different levels of fungal mycotoxins and spray-dried porcine plasma have improved weight gain, feed intake and reduced diarrhea incidence. Microbial Pathogenesis 117, 259-264.

Muns, R., Nuntapaitoon, M., \& Tummaruk, P. (2017). Effect of oral supplementation with different energy boosters in newborn piglets on pre-weaning mortality, growth and serological levels of IGF-I and IgG. Journal of Animal Science 95, 353-360.

Perry, A. M., O'Sullivan, T. L., Harding, J. C. S., Wood, R.D., \& Friendship, R. M. (2017). Hematology and biochemistry reference intervals for Ontario commercial nursing pigs close to the time of weaning. The Canadian Veterinary Journal 58, 371-376.

Quesnel, H., Farmer, C., \& Devillers, N. 2012. Colostrum intake: Influence on piglet performance and factors of variation. Livestock Science 146, 105-114.

Pereira, A. S. (2018). Methodology of scientific research. [e-Book]. Santa Maria City. UAB/NTE/UFSM Editors. Accessed on: June, 12th, 2020. Available at: https://repositorio.ufsm.br/bitstream/handle/1/15824/Lic_Computacao_MetodologiaPesquisa-Cientifica.pdf?sequence $=1$. 
Remus, A., Andretta, I., Kipper, M. C., Lehnen, C. R., Klein, C. C., Lovatto, P. A., \& Hauschild, L. (2013). A meta-analytical study about the relation of blood plasma addition in diets for piglets in the post-weaning and productive performance variables. Livestock Science $155,294-300$.

Rostagno, H. S., Albino, L. F. T., Hannas, M. I., Donzele, J. L., Sakomura, N. K., Perazzo, F. G., Saraiva, A., Teixeira, M. L., Rodrigues, P. B., Oliveira, R. F., Barreto, S. L. T., \& Brito, C. O. 2017. Tabelas brasileiras para aves e suínos: composição de alimentos e exigências nutricionais. $4^{\text {th }}$ ed. UFV DZO MG, Viçosa.

Svendsen, J., Weström, B. R., \& Olsson, A. C. (2005). Intestinal macromolecular transmission in newborn pigs: Implications for management of neonatal pig survival and health. Livestock Production Science 97, 183-191.

Schuh, S., Müller, L. K. F., Campos L. P., Moresco, R. N., Baldissera M. D., Oliveira S. C., Campigotto, G., Silva A. S., \& Paiano, D. (2016). Effect of supplementation of newborn piglets with spray dry blood plasma on weight gain and serum biochemical variables. Comparative Clinical Pathology 25, 1029-1033.

Stoll, B., Henry, J., Reeds, P. J., Yu, H., Jahoor, F., \& Burrin, D. G. (1998). Catabolism dominates the first-pass intestinal metabolism of dietary essential amino acids in milk proteinfed piglets. Journal of Nutrition 128, 606-614.

Torrallardona, D. (2010). Spray Dried Animal Plasma as an Alternative to Antibiotics in Weanling Pigs - A Review. Asian-Australasian Journal of Animal Sciences 23, 131-148.

Theil, P. K., Lauridsen, C. A., \& Quesnel, H. (2014). Neonatal piglet survival: impact of sow nutrition around parturition on fetal glycogen deposition and production and composition of colostrum and transient milk. Animal 8, 1021-1030.

Vallet, J. L., Miles, J. R., \& Rempel, L. A. (2013). A simple novel measure of passive transfer of maternal immunoglobulin is predictive of preweaning mortality in piglets. Veterinary Journal 195, 91-97. 
Viott, R. C., Menezes, T. A., Mellagi, A. P. G., Bernardi, M. L., Wentz, I., \& Bortolozzo, F. P. (2018). Performance of low birth-weight piglets upon protein-energy and/or colostrum supplementation. Arquivo Brasileiro de Medicina Veterinária e Zootecnia 70, 1293-1300.

Weaver, A. C., Campbell, J. M., Crenshaw, J. D., Polo, J., \& Kim S. W. 2014. Efficacy of dietary spray dried plasma protein to mitigate the negative effects on performance of pigs fed diets with corn naturally contaminated with multiple mycotoxins. Journal of Animal Science 92, 3878-3886.

Wu, W. Z., Wang, X. Q., Wu, G. Y., Kim, S. W., Chen F., \& Wang, J. J. (2010). Differential composition of proteomes in sow colostrum and milk from anterior and posterior mammary glands. Journal of Animal Science 88, 2657-2664.

\section{Percentage of contribution of each author in the manuscript}

$$
\begin{gathered}
\text { Dirceu Vicari Junior - 20\% } \\
\text { Fernando Zimmer - 15\% } \\
\text { Jeferson Gugel - } 15 \% \\
\text { Gabriela Campigotto }-10 \%
\end{gathered}
$$

Fernando de Castro Tavernari - 5\%

Marcel M. Boiago - 5\%

Aleksandro Schafer da Silva - 10\%

Diovani Paiano - 20\% 